TITLE:

\title{
Underground Vertical Distributions of Macrofauna and Root in a Mangrove Forest of Southern Thailand
}

\section{$\operatorname{AUTHOR}(S)$ :}

Wada, Keiji; Komiyama, Akira; Ogino, Kazuhiko

\section{CITATION:}

Wada, Keiji ... [et al]. Underground Vertical Distributions of Macrofauna and Root in a Mangrove Forest of Southern Thailand. PUBLICATIONS OF THE SETO MARINE BIOLOGICAL LABORATORY 1987, 32(4-6): 329-333

ISSUE DATE:

1987-12-26

URL:

http://hdl.handle.net/2433/176139

RIGHT: 


\title{
Underground Vertical Distributions of Macrofauna and Root in a Mangrove Forest of Southern Thailand
}

\author{
By \\ Keiji Wada \\ Seto Marine Biological Laboratory, Kyoto University, Shirahama, \\ Wakayama, 649-22, Japan
}

Akira Komiyama

Faculty of Agriculture, Gifu University, Gifu, 501-11, Japan

and

Kazuhiko Ogino

Faculty of Agriculture, Ehime University, Ehime, 790, Japan

With Text-figure 1 and Table 1

\begin{abstract}
In a mangrove forest of southern Thailand, underground vertical distributions of macrofauna and root biomass were investigated to a depth of $1 \mathrm{~m}$. While smaller roots were distributed more or Iess evenly, larger roots were restricted to shallower layers. Animals were more abundant in shallower layers, but some of them penetrated into the deepest. Relation between the distribution of animals and that of larger roots is discussed.
\end{abstract}

Cross-shore and/or along-shore distributions of the benthic macrofauna in mangrove swamp have been studied quantitatively in various parts of the world (e.g. Warner, 1969; Day, 1974; Sasekumar, 1974; Frith et al., 1976; Shokita et al., 1983; Shihe \& Fuxue, 1985). But the quantitative data on the underground vertical distribution of it have not so far been presented. One of the reason is probably that matted roots of mangrove trees make it difficult to dig the substrate deeper. In the temperate salt marsh habitat, the root mat density of the plants has been known to play an important role in controlling the distribution of fiddler crabs (Ringold, 1979; Bertness \& Miller, 1984). Likewise, the underground root system of mangrove forest is assumed to influence more or less the distribution of the burrowing animals there. In this paper, we report the vertical distribution of benthic macrofauna in relation to the root biomass in a mangrove forest of southern Thailand.

\section{Study site and methods}

The study site was located in a mangrove forest at Hatsaikhao village near Ranong ( $9^{\circ} 58^{\prime} \mathrm{N}$,

Publ. Seto Mar. Biol. Lab., 32 (4/6), 329-333, 1987.

(Article 12) 
$98^{\circ} 38^{\prime} \mathrm{E}$ ), southern Thailand. In December 1982, a plot of $15 \mathrm{~m} \times 20 \mathrm{~m}$ was established about 50 $\mathrm{m}$ landward from the seaward fringe of the forest. The plot area was not flooded at normal high tides and the substratum was sandy mud, with scattered puddles in places. The temperature and salinity of the water in a puddle measured at $10: 00$ on $1 \mathrm{Dec}$. were $27.0^{\circ} \mathrm{C}$ and $27.28 \%$, respectively. The dominant tree species in the plot was Rhizophora apiculata Blume with only a few smaller trees of Bruguiera gymnorhiza (L.) Lam. and B. cylindrica (L.) Blume. The maximum diameter and height of the trees were $44.5 \mathrm{~cm}$ and $37.2 \mathrm{~m}$, respectively. The basal area totalled $31.3 \mathrm{~m}^{2} / \mathrm{ha}$ and the stand density was 733 trees/ha. Shrub measurements were $31500 /$ ha in the density, $7.5 \mathrm{~m}^{2} / \mathrm{ha}$ in basal area, $2.4 \mathrm{~cm}$ in mean diameter and $3.1 \mathrm{~m}$ in mean height.

A trench $(0.2 \mathrm{~m} \times 15.5 \mathrm{~m})$ was laid out in the plot between two big trees of $R$. apiculata (diameter: 44.5 and $43.6 \mathrm{~cm}$ ). Fresh weight of prop roots/pneumatophores above the ground of the trench totalled $63.8 \mathrm{~kg}$. The water table of the trench was $28-30 \mathrm{~cm}$ deep and the temperature and salinity of the underground water were $25.0^{\circ} \mathrm{C}$ and $22.98 \%$, respectively (10:10 on 9 Dec.). The trench was subdivided into 31 compartments, each $0.5 \mathrm{~m}$ long and each compartment was further subdivided vertically into 10 layers of soil blocks to a depth of $1.0 \mathrm{~m}$. The 310 soil blocks, each $0.2 \mathrm{~m}$ (width) $\times$ $0.5 \mathrm{~m}$ (length) $\times 0.1 \mathrm{~m}$ (depth), were cut by a hand saw from the smoothed wall of the trench. Each soil block was sieved by a net with $1 \mathrm{~mm}$ opening to collect living roots and animals. Living roots were sorted into eight diameter classes $(<2 \mathrm{~mm}, 2-5 \mathrm{~mm}, 5-10 \mathrm{~mm}, 10-20 \mathrm{~mm}, 20-30 \mathrm{~mm}, 30-40$ $\mathrm{mm}, 40-50 \mathrm{~mm}$ and $>50 \mathrm{~mm}$ ) and weighed fresh. Animals were fixed in $10 \%$ sea-water formalin and the number of individuals of each species was recorded for each soil block.

\section{Results}

Total fresh weight of underground living roots from the trench $\left(3.1 \mathrm{~m}^{3}\right)$ was $455.2 \mathrm{~kg}, 79.0 \%(359.8 \mathrm{~kg})$ of which was constituted by fine roots $(<2 \mathrm{~mm}$ in diameter). The vertical distribution of the fresh root weight is illustrated in Fig. 1. Fine roots showed considerably greater weights than other roots in all the depth layers. The weight of fine roots as well as small roots $(2-10 \mathrm{~mm})$ was lowest in the uppermost layer and distributed more or less evenly from $10-20 \mathrm{~cm}$ layer to the bottom. The roots of $10-20 \mathrm{~mm}$ were abundant in the $10-60 \mathrm{~cm}$ layers and below

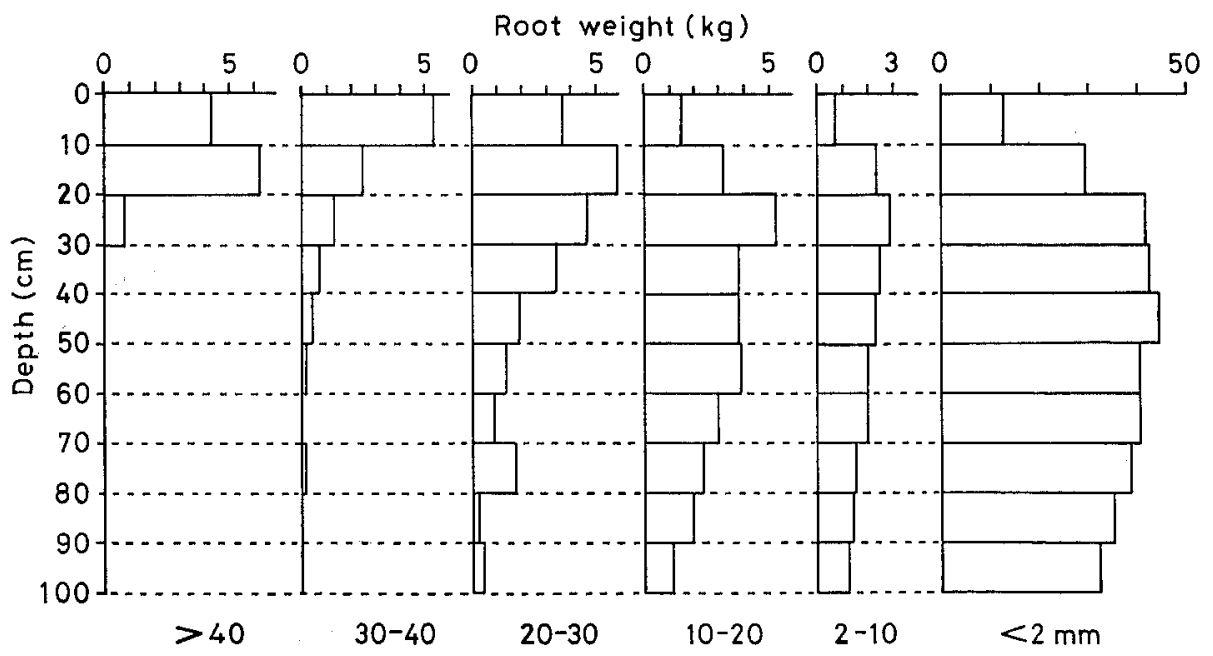

Fig. 1. Vertical distribution of fresh root weight per a layer $\left(3.1 \mathrm{~m}^{2} \times 10 \mathrm{~cm}\right.$ deep $)$ of the trench, separately for 6 diameter classes. 
Table 1. Number of individuals of each animal species collected in each depth layer of the trench. Number of species from each layer is also shown.

\begin{tabular}{|c|c|c|c|c|c|c|c|c|c|c|}
\hline \multirow{2}{*}{ Species } & \multicolumn{10}{|c|}{ Depth in $\mathrm{cm}$} \\
\hline & $0-10$ & $10-20$ & $20-30$ & $30-40$ & $40-50$ & $50-60$ & $60-70$ & $70-80$ & $80-90$ & $90-100$ \\
\hline \multicolumn{11}{|l|}{ Polychaeta } \\
\hline Leonnantes sp. & 1 & 2 & 3 & 2 & 1 & & & & & \\
\hline Glycera sp. & & 1 & & 1 & 2 & 2 & & & & \\
\hline Dasybranchus sp. & 1 & 8 & & & & & & & & \\
\hline \multicolumn{11}{|l|}{ Decapoda } \\
\hline Alpheus euphrosyne & & 4 & & 1 & 1 & 1 & & 1 & 1 & 1 \\
\hline Callianasa ranongensis & 2 & 3 & 4 & 2 & 5 & 2 & 1 & 3 & 1 & 1 \\
\hline \multicolumn{11}{|l|}{ Brachyura } \\
\hline Chiromanthes haswelli & 6 & 2 & 1 & 2 & & & & & & \\
\hline Sarmatium germaini & & 2 & 3 & & & & & & & \\
\hline Neosarmatium smithi & 4 & 1 & 1 & & & 1 & & & & \\
\hline Clistocoeloma merguiensis & 2 & 1 & & & & & & & & \\
\hline$U c a$ sp. & 1 & & & & & & & & & \\
\hline \multicolumn{11}{|l|}{ Other invertebrates } \\
\hline Actiniaria sp. & 1 & & & & & & & & & \\
\hline Assiminea brevicula & 3 & & & & & & & & & \\
\hline Galeommatacea sp. & & & & 1 & & 1 & & & & \\
\hline Sipunculoidea sp. & & 1 & & & & & & & & \\
\hline Diptera larva sp. 1 & 8 & 15 & & & & & & & & \\
\hline sp. 2 & 4 & & & & & & & & & \\
\hline No. of species & 11 & 11 & 5 & 6 & 4 & 5 & 1 & 2 & 2 & 2 \\
\hline
\end{tabular}

the depth of $60 \mathrm{~cm}$ their weight decreased with the depth. The weight of the roots of $20-30 \mathrm{~mm}$ and $30-40 \mathrm{~mm}$ was large in the top $20 \mathrm{~cm}$ layers and decreased downward to the depth of about $60 \mathrm{~cm}$, below which their amounts were very small. The roots of $>40 \mathrm{~mm}$ were mostly restricted to the top $20 \mathrm{~cm}$ layers.

Table 1 gives the vertical distribution of each collected animal species. Sixteen species were collected in total and 15 of them were recorded from the top $20 \mathrm{~cm}$ layers. Number of species was maximum (11) both in the $0-10 \mathrm{~cm}$ and $10-20 \mathrm{~cm}$ layers, decreased to 4-6 species in each of $20-60 \mathrm{~cm}$ layers, and below the depth of $60 \mathrm{~cm}$ only 2 species (Alpheus euphrosyne and Callianasa ranongensis) occurred. Two decapods, $A$. euphrosyne and $C$. ranongensis, were collected throughout the sampling layers. Two polychaetes and 3 grapsid crabs occurred from the top to the depths of $30-60 \mathrm{~cm}$. Other 8 species excluding a lamellibranch, Galeommatacea sp., were restricted to the top $20 \mathrm{~cm}$ layers.

\section{Discussion}

Macrofauna was more abundant in shallower layers of the substrate. The upper 0-20 cm layers had almost all of the animal species recorded from all the layers. 
Number of the species per a layer decreased rapidly from 10-20 cm layer to $20-30$ $\mathrm{cm}$ and from $50-60 \mathrm{~cm}$ layer to $60-70 \mathrm{~cm}$. As with the root distribution, on the other hand, the large roots of $>40 \mathrm{~mm}$ were mostly restricted to the upper $0-20 \mathrm{~cm}$ layers. The roots of $20-40 \mathrm{~mm}$ were considerably less abundant below the depth of $60 \mathrm{~cm}$, compared with those above the depth. In contrast, the fine and small roots of $<10 \mathrm{~mm}$ were distributed more or less evenly from the depth of $10 \mathrm{~cm}$ to the bottom of the trench. These facts suggest that there are some associative relations between larger roots and animal distribution. On digging the trench, we found the burrows of some decapods ran along larger roots; this phenomenon may be one of the possible relations. Bertness \& Miller (1984) reported that in a salt marsh many of the burrows of the fiddler crab Uca pugnax were found immediately adjacent to subsurface structural elements such as grass stems.

The density of mangrove infauna has hitherto been investigated by digging up the substrate to the depth of 15-25 cm (Day, 1974; Sasekumar, 1974; Frith et al., 1976; Shokita et al., 1983). According to the present result, the animals were more abundant above the depth of $20 \mathrm{~cm}$ than below it. But half of the species recorded from the whole trench occurred also below the depth of $20 \mathrm{~cm}$. In 2 polychaetes, 3 decapods and 1 lamellibranch, their number of collected individuals was larger below the depth of $20 \mathrm{~cm}$ than above it. Thus, it can be said that the digging depth of $15-25 \mathrm{~cm}$ is insufficient to obtain the accurate density of mangrove infauna, especially of polychaetes and decapods, at least in the supralittoral forested area.

\section{Acknowledgement}

Our sincere thanks are due to Dr. S. Sabhasri, Dr. S. Aksornkoae, Miss P. Thanaskarn, Mr. J. Konsangchai, and the staff of the National Research Council, the Royal Forest Department and Phuket Marine Biological Center for their cooperation in the study. Messrs. P. Serivattana, V. Jintana, W. Thappididh and S. Ohnishi gave most effective help to us in the field survey. The following persons kindly helped with the identification of taxa: Drs. M. Tsuchiya (polychaetes), M. Miya (Alpheus) and K. Sakai (Callianasa). Comments made by Drs. E. Harada and T. Itô on the manuscript were also helpful. This work was supported financially by Grant-in-Aid for Overseas Scientific Survey, No. 57041018 (led by Prof. A. Miyawaki, Yokohama National University), from the Japan Ministry of Education, Science and Culture.

\section{References}

Bertness, M.D. \& T. Miller. 1984. The distribution and dynamics of Uca pugnax (Smith) burrows in a New England salt marsh. J. Exp. Mar. Biol. Ecol., 83: 211-237.

Day, J.H. 1974. The ecology of Morrumbene Estuary, Moçambique. Trans. Roy. Soc. S. Afr., $41: 43-97$.

Frith, D.W., R. Tantanasiriwong \& O. Bhatia. 1976. Zonation of macrofauna on a mangrove shore, Phuket Island. Phuket Mar. Biol. Center Res. Bull., 10: 1-37.

Ringold, P. 1979. Burrowing, root mat density, and the distribution of fiddler crabs in the eastern United States. J. Exp. Mar. Biol. Ecol., 36: 11-21.

Sasekumar, A. 1974. Distribution of macrofauna on a Malayan mangrove shore. J. Anim. Ecol., 43: 51-69. 
Shihe, G. \& L. Fuxue. 1985. Community ecology of ground-dwelling macrofauna of mangrove in the Jiulong Jiang Estuary, Fujian. Taiwan Strait, 4: 179-191.

Shokita, S., K. Nozawa, N. Yoshikawa \& S. Limsakul. 1983. Macrofauna in mangrove areas of Thailand. In: K. Nozawa ed., Mangrove ecology in Thailand, pp. 33-61. Kagoshima University, Kagoshima.

Warner, G.F. 1969. The occurrence and distribution of crabs in a Jamaican mangrove swamp. J. Anim. Ecol., 38: 379-389. 